\title{
THE EFFECT OF LAND PLANNING ON CO2 CARBON PRODUCTION AND THEIR EFFECT ON GROSS REGIONAL DOMESTIC PRODUCTS (GRDP) RIAU PROVINCE
}

Rita

Swadharma Institute of Technology and Business, Indonesia

Email: rita@swadharna.ac.id

\begin{tabular}{|c|c|}
\hline ARTICLE INFO & ABSTRACT \\
\hline $\begin{array}{l}\text { Received: } \\
\text { January, } 26^{\text {th }} \\
2022 \\
\text { Revised: } \\
\text { February, } 17^{\text {th }} \\
2022 \\
\text { Approved: } \\
\text { February, } 18^{\text {th }} \\
2022\end{array}$ & $\begin{array}{l}\text { This study aims to analyze the effect of land clearing on CO2 } \\
\text { carbon production due to forest fires that often occur in Riau } \\
\text { Province in 2018-2019, and to analyze the opportunities for } \\
\text { forest fires to occur in Riau Province using available data. The } \\
\text { results of the logistic regression show that forest fires are } \\
\text { more likely to occur in peaty forests even though in reality the } \\
\text { soil is not peaty in Riau. Land clearing causes the emission of } \\
\text { carbon dioxide (CO2) gas into the atmosphere, including the } \\
\text { conversion of forests to small-scale agriculture. The aim of } \\
\text { the study was to measure CO2 emissions from an economic } \\
\text { perspective due to land clearing for plantations by regional } \\
\text { domestic product companies (GRDP), such as rubber } \\
\text { plantations (Hevea brasiliensis) aged 8-10 years, oil palm } \\
\text { (Elaeis guineensis Jacq) plantations aged 5-6 years. and } \\
\text { ginger (Zingiber officinale) aged 0-6 months. The conversion } \\
\text { of HRG was originally intended to obtain economic benefits in } \\
\text { the form of an increase in the gross regional domestic } \\
\text { product (GRDP) of the plantation sector. However, these } \\
\text { efforts have also led to the loss of the benefits of HRG } \\
\text { environmental services. This paper is intended to provide an } \\
\text { overview of the economic value of the lost environmental } \\
\text { services as a result of the conversion and degradation of HRG } \\
\text { Riau and its impact on sustainable development and to } \\
\text { consider the potential for restoration as an effort towards } \\
\text { sustainable economic development. The results showed that } \\
\text { CO2 from the opening had a contribution to increase the }\end{array}$ \\
\hline
\end{tabular}

Rita. (2022). The Effect of Land Planning on Co2 Carbon Production on Their Effect on Gross Regional Domestic Products (GRDP) Riau

How to cite: $\quad$ Province. Journal Eduvest. Vol 2(2): 259-269

E-ISSN:

Published by: https://greenpublisher.id/ 


\begin{tabular}{ll}
\hline & $\begin{array}{l}\text { concentration of } \mathrm{CO} 2 \text { in the atmosphere. Carbon control from } \\
\text { small-scale agriculture on peatlands makes an important } \\
\text { contribution to achieving the target for reducing greenhouse } \\
\text { gas emissions from the agricultural sector. }\end{array}$ \\
\hline KEYWORDS & Land Clearing, CO2 Emissions, Plantations, GRDP \\
\hline CC) (5) (O) & $\begin{array}{l}\text { This work is licensed under a Creative Commons } \\
\text { Attribution-ShareAlike 4.0 International }\end{array}$ \\
\hline
\end{tabular}

\section{INTRODUCTION}

Forests are one of the most influential commodities in Indonesia, both as a source of balancing ecosystems to as an economic source for many Indonesian citizens. Unfortunately, these commodities are widely misused by irresponsible persons, both by corporations and by individuals. Forest fires in Indonesia are currently seen as a regional and global disaster. This is due to the impact of forest fires that have spread to neighboring countries and gases emitted from combustion to the atmosphere (such as $\mathrm{CO} 2$ ) have the potential to cause global warming. In recent years, forest fires have often occurred every year, especially during the dry season. According to WWF records, every minute in the world there is forest destruction equal to 37 football fields, including Indonesian forests. Based on records from the Ministry of Forestry of the Republic of Indonesia, at least 1.1 million hectares or $2 \%$ of Indonesia's forests are shrinking every year. Data from the Ministry of Forestry shows that of the approximately 130 million hectares of forest remaining in Indonesia, 42 million hectares of them have been cut down or burned. If we examine, forest fires in Indonesia in 2015 have not yet been brought to trial by the court and received a judge's decision. valid and permanent, even though this forest burning crime has been included in the White Collar Crime, Corporate Crime and Extraordinary Crime. Because in general, it is known because of land preparation activities for various forms of forestry business, which can also be enlarged due to the climate (Anih Sri Suryani., 2012). Ecologically, forest area decline and land degradation due to fires pose risks and uncertainties in the restoration of ecosystem conditions, loss of value for future uses of timber and non-timber forests and loss of expected value of currently untapped biodiversity (Bahruni et al. , 2007). Several research results show that forest and land fires are caused by various environmental factors such as climate, land cover conditions, soil types, and other bio-physical environmental factors; socioeconomic factors and policy factors that can increase human interaction with forests and land (Tarigan, 2015, Ruchiat, 2001). According to Ekadinata and Dewi (2011) the number of land use conversion activities caused by the socio-economic conditions of the community and land tenure policies are the main causes of the high number of forest fires in Indonesia. It is therefore necessary to reform forestry policies and land use regulations based on land use (Barber and Schweithelm, 2000), especially in highly vulnerable ecosystems such as peatlands. Riau Province is one area that needs special attention because it has a peatland area of 3,867,413 ha or $43.61 \%$ of the total area (Ministry of Agriculture, 2011).

The availability of data/information about the level of vulnerability and potential for forest and land fires in Riau Province is important. Geographic Information System (GIS) is one method that can facilitate stakeholders in monitoring and understanding the occurrence of forest fires, whether these incidents have occurred or predictions of future fires. Spatial modeling of forest and land fires has become a topic of study by many 
researchers, using various approaches and considerations, including environmental (biophysical), socio-economic and policy factors. Jaya et al. (2007) modeled fires using variations in local climate patterns (rainfall), vegetation (land cover, biomass density, and humidity), land use and related factors such as distance from rivers, roads and settlements. Saito et al. (2002) assessed the relationship between hotspots and road/river accessibility as an important factor in mapping fire risk maps. The occurrence of forest and land fires is triggered by various factors, both natural and human factors. Natural factors that often trigger forest and land fires are extreme climatic conditions, such as a prolonged dry season due to the El Nino phenomenon. Based on the research of Saharjo and Husaeni (1998), forest and land fires in Indonesia are thought to be caused by the influence of human activities rather than natural factors. However, a quantitative analysis is needed that explains the relationship and the role of each factor that significantly influences the occurrence of forest and land fires. Different environmental characteristics in each region lead to the need for research that can be a reference in effective and efficient fire control in Riau Province.

The area of peatland in Indonesia is estimated at 20.6 million ha and 4.1 million ha in Riau Province. Utilization of peatland for plantations reaches 817,593 ha of the total plantation area of 2.6 million ha. While the area of peat land in Bengkalis Regency reaches 856,386 ha with a plantation area of 102,858.5 ha (Dinas Perkebunan Riau Province 2009). The conversion of forest land into oil palm plantations in the peat swamp ecosystem is the dominant factor causing peatland degradation (Riwandi 2003). Land clearing activities that do not pay attention to environmental biophysical characteristics have caused peatlands to degrade and become abandoned lands (Noorginayuwati et al. 1997; Sutikno et al. 1998 referred to in Noor 2001). Oil palm development on peatlands is also faced with the problem of potential $\mathrm{CO} 2$ emissions as a greenhouse gas (GHG) (Hooijer et al. 2006), and the loss of biodiversity (Noor 2001; Riwandi 2003). Land clearing in peat swamp forest into oil palm plantations in a 25 year cropping cycle is estimated to produce an average net $\mathrm{CO} 2$ emission of 41 tonnes ha-1 year-1 (Agus et al. 2009). In the 1990-2007 period, the total CO2 emissions resulting from forest degradation, fires and peat decomposition in Riau reached $3.66 \mathrm{G}$ tons of $\mathrm{CO} 2$ (WWF 2008). The use of peatlands for plantation business in Bengkalis Regency has not been able to maintain the sustainability of the ecological functions of the ecosystem. This can be seen from the degradation of peatlands that occur such as land subsidence and dry events that do not return. This condition causes land fires in the dry season and floods in the rainy season. The agroecology of oil palm plantations is a very complex and dynamic system. System dynamics are formed from various interactions between vegetation, nutrient cycles and hydrology (Meiling \& Goh 2008). Oil palm plantations on peatlands are expected to apply the ecological principles of the area based on the optimization and conservation of resources.

It is undeniable that the conversion and utilization of HRG for agricultural, plantation and forestry cultivation provides economic benefits, among others in the form of employment and increasing production in the agricultural sector. These benefits are recorded in the GDP. However, in addition to the economic benefits that can be achieved, on the other hand, environmental benefits have been sacrificed or known as negative externalities. Unfortunately, the public does not know the value of these externalities, because the loss of these benefits is not recorded in GRDP.

The role of HRG in producing various types of goods such as plantations is recorded in the conventional economic indicators (GRDP), while the value of the benefits of environmental services, which include waste neutralizer, carbon dioxide absorber, and 
regulator of the hydrological system, has not been recorded in GRDP. Attention to various types of goods produced by HRG but not followed by concern for the benefits of environmental services is feared will further increase the exploitation of HRG which in the end can lead to bankruptcy of economic development. Starting from the theoretical basis above and supported by the theory of sustainable income proposed by Hicks (1946), this study was conducted to examine changes in HRG availability in South Sumatra, as well as the potential for restoration efforts as a reinvestment effort to maintain HRG capacity in achieving development. sustainable economy. Both income and sustainable economic development are related, because income is an indicator used to assess the performance of economic development. What is meant by sustainable income is the amount of revenue that can be used for consumption activities in such a way that it does not reduce wealth (potential income in the future).

\section{RESEARCH METHOD}

This research method is to analyze the secondary data that has been collected and conduct field observation methods to obtain model validation data. The research stages consist of collecting environmental biophysical data, socio-economic community and government policies, and spatial analysis of forest and land fires. The data needed in this research are:

a. Hotspot data obtained from the ASEAN Specialized Meteorological Center (ASMC) accessed through http://asmc.asean.org (Singapore Weather Information Portal) and the Ministry of Environment and Forestry (KLHK), ) Rainfall data from the BMKG (Badan Meteorology, Climatology) and Geophysics),

b. Soil type map from the Ministry of Agriculture (Indonesian Center for Agricultural Research and Development),

c. Land cover map from the Ministry of Environment and Forestry,

d. Bumi Indonesia Map with a scale of 1:25000/1:50,000 (thematic roads, rivers, etc.),

e. Socio-economic tabulated data for all districts in Riau Province from Statistics Indonesia,

f. Provincial Spatial Planning Map (RTRW) / D) Land use status,

a. Forest Area Map,

g. mining business license concessions and Timber Forest Product Utilization Permits, both natural and plantation forests (formerly Forest Concession Rights and Industrial Plantation Forests),

h. Regional boundary data and

i. Law and law enforcement.

Determination of the unit of analysis

In this study, the bio-physical characteristics of the environment were carried out in the analysis unit with a box size of $250 \mathrm{~m} \times 250 \mathrm{~m}$, while the socio-economic characteristics were carried out in the village analysis unit as the unit of observation area. Each variable attribute in the unit of analysis will be used as input in the statistical analysis process. Fill value for each grid

This is done by calculating the distance (Euclidean distance) to the input variable. Each grid will be filled by the value of the distance attribute of each variable, both dependent and independent variables used in this study. Grid attribute filling is done using an additional module of the ArcGIS Hawth Tools software. This module will fill the grid attribute with the distance of each variable on each grid in linear units. Next, 
filling in the attribute grid for socio-economic and policy variables is done using the Zonal Attribute algorithm.

Hotspot data collection as the dependent variable.

Hotspot data analysis was carried out by plotting hotspots for the last 9 years (2007-2015) to show the hotspot position and distribution in the research location so that the fire potential of the research area could be obtained (Figure 2). Determination of the location of hotspot data collection as the dependent variable is carried out by considering the spread of hotspots on a grid size of $5 \mathrm{~km} \times 5 \mathrm{~km}$. To ensure that the hotspot location can be used as a representative dependent variable, a grid having a hotspot number greater than 50 points will be taken to represent the hotspot data to be included in the statistical analysis process. Each selected grid will be represented by only one hotspot data.

Spatial analysis and spatial modeling with Logistics Regression method

Regression is a statistical analysis that can be used to obtain the coefficients of the empirical relationship from the observations made. The dependent variable of the logistic regression can be either binary or categorical. The independent variable (logistic regression) can be a combination of continuous and categorical variables. The general form of logistic regression can be seen in the following equation: $P i=\frac{1}{1+\exp \left[-\left(\beta_{0}+\sum_{j=1}^{k} \beta_{j} x_{j i}\right)\right]}$

Description:

Pi :Probability/opportunity

$0,1 . . \mathrm{k}$ : Coefficient of measurement result

$\mathrm{X} 1, \mathrm{X} 2 . . \mathrm{Xk}$ : Variable/independent variable

This equation shows the probability of a fire occurring, which is represented by a binary response variable ( 1 and 0$)$. A value of 1 indicates fire, while a value of 0 indicates no fire (Xie et al., 2005). To model fires by logistic regression, the spatial diversity of the data must be considered. Spatial statistics such as spatial dependence and spatial sampling should be considered in logistic regression with the aim of eliminating automatic spatial correlation (Xie et al., 2005). The results of logistic regression analysis will show the variables that have the most influence on the occurrence of fires. Determination of criteria for the Logistics Regression model. Hotspot or burnt area data is the dependent variable in the logistic regression model. In this study, the hotspots or area criteria used for parameter $\mathrm{Y}$ are the number of hotspots per grid $>50$ for criteria 1 and $<50$ for criteria 0 , where each grid will only be represented by one hotspot point (1 point per grid). As explained above, to relate the interaction of biophysical factors, socio-economic factors and policy factors in the spatial model of forest and land fires in Riau Province using a logistic regression model. This regression model has been used to determine the interaction of environmental factors and land use change in Java (Verburg et al., 2004), a spatial model for deforestation (Prasetyo et al., 2009), and studies of land use change at a regional scale (Setiawan, 2010). 2013).

Measurement and sampling were carried out on each land once a month for four months. Measurements of the temperature and depth of the groundwater table were carried out at the same time as gas sampling. Sampling of gas was carried out by the closed hood method. The mask used is a cylindrical shape with a diameter of $35 \mathrm{~cm}$ and a height of $40 \mathrm{~cm}$ which has been equipped with a septum where the syringe / syringe is used. The gas sample was aspirated from the lid using a $20 \mathrm{ml}$ syringe and then stored in a $10 \mathrm{ml}$ vial. Sampling was carried out at 08.00-15.00. each point 4 times every 4 
minutes. The total samples taken were 536 sample tubes for four months. Samples were taken from six points of the rhizosphere area and six points of the non-rhizosphere area in the oil palm area. The same thing was also done in rubber and ginger fields. Air temperature and soil temperature were measured at the time of sampling. Surface temperature measurement is done by placing a thermometer above the gas sampling hood or about $40 \mathrm{~cm}$ from the ground surface. Soil temperature measurements were carried out at the point of gas collection at a depth of $5 \mathrm{~cm}$ and $10 \mathrm{~cm}$ from the ground surface. Measurements of air temperature and soil temperature are carried out simultaneously when taking gas. The gas samples that have been taken are taken to the laboratory for analysis. The gas sample was measured by gas chromatography to determine the concentration of $\mathrm{CO} 2$ emissions in the vial. Measurements were made at the University of Notthingham Laboratory, UK. The emission concentrations measured in gas chromatography are then converted to $\mathrm{CO} 2$ emissions using the Ideal Gas Law. The data obtained are presented by descriptive statistical analysis. Comparison of $\mathrm{CO} 2$ emissions in the rhizosphere and non-rhizosphere using ANOVA and average comparison analysis with $\mathrm{t}$ test. Comparison of $\mathrm{CO} 2$ emissions in the rhizosphere and non-rhizosphere using the average comparison with the $t$ test. To examine the effect of land use on $\mathrm{CO} 2$ emissions, a diversity analysis was carried out. The relationship between $\mathrm{CO} 2$ emissions and groundwater table depth, temperature and $\mathrm{pH}$ was tested by Pearson correlation and simple linear regression.

\section{RESULT AND DISCUSSION}

\section{Some Soil Properties}

The soil properties measured included peat thickness, bulk density and $\mathrm{pH}$. Peat soils at the study site include thin peat $(\leq 40 \mathrm{~cm})$ to very deep peat $(\geq 300 \mathrm{~cm})$. In OP land, the thickness of peat is classified as very deep peat with an average thickness of 365 $\mathrm{cm}$. In RB land, the thickness of peat is classified as deep peat with an average thickness of $213 \mathrm{~cm}$. In GG land, the peat thickness is classified as shallow peat with an average thickness of $80 \mathrm{~cm}$. The density of oil palm (OP) and ginger (GG) fields was $0.21 \mathrm{~g} \mathrm{~cm}-3$ and on rubber $(\mathrm{RB})$ was $0.15 \mathrm{~g} \mathrm{~cm}-3$. Thin peat that contains a lot of mineral soil affects the high density of OP and GG. The degree of soil acidity $(\mathrm{pH})$ is classified as very acidic $(<4.5)$ based on the criteria for soil chemical properties (Soil Research Center 2009). The highest $\mathrm{pH}$ values were found in rubber fields with a value of 4.07 and oil palm and ginger fields respectively 3.98 and 3.90 . 
Table 1 Thickness, Peat Soil Properties, Environmental Variables and CO2 Emissions

\begin{tabular}{|c|c|c|c|c|c|c|c|c|c|}
\hline Lahan & Ulangan & $\begin{array}{c}\text { Ketebalan } \\
\text { Gambut }(\mathrm{cm})\end{array}$ & $\begin{array}{l}\text { Bobot isi } \\
\left(\mathrm{g} \mathrm{cm}^{-3}\right)\end{array}$ & $\mathrm{pH}$ tanah & $\mathrm{pH}$ Air & $\begin{array}{l}\text { Suhu } \\
\text { Udara } \\
\left.\text { ( }{ }^{\circ} \mathrm{C}\right)\end{array}$ & $\begin{array}{c}\text { Suhu } \\
\text { Tanah } 5 \\
\mathrm{~cm}\left({ }^{\circ} \mathrm{C}\right)\end{array}$ & $\begin{array}{c}\text { Suhu } \\
\text { Tanah } 10 \text { Muka Air } \\
\mathrm{cm}\left({ }^{\circ} \mathrm{C}\right)\end{array}$ & $\begin{array}{c}\text { Emisi } \mathrm{CO}_{2} \mathrm{mg} \\
\mathrm{m}^{-2} \mathrm{~h}^{-1}\end{array}$ \\
\hline \multirow{4}{*}{ Karet } & 1 & 410 & 0,09 & 4,08 & $3,7 \pm 0,07$ & $30,9 \pm 2,1$ & $27,3 \pm 1,0$ & $26,9 \pm 0,6 \quad 36,4 \pm 0,5$ & $408,5 \pm 136,4$ \\
\hline & 2 & 114 & 0,13 & 3,95 & $3,5 \pm 0,13$ & $29,5 \pm 1,5$ & $26,8 \pm 0,8$ & $26,5 \pm 0,339,3 \pm 10,3$ & $538,4 \pm 158,2$ \\
\hline & 3 & 115 & 0,22 & 4,2 & $3,5 \pm 0,05$ & $31,0 \pm 1,0$ & $27,5 \pm 0,4$ & $27,2 \pm 0,2 \quad 33,3 \pm 5,3$ & $434,8 \pm 131,4$ \\
\hline & Rerata & 213 & 0,15 & 4,08 & $3,5 \pm 0,12$ & $30,5 \pm 1,7$ & $27,2 \pm 0,8$ & $26,9 \pm 0,5 \quad 36,5 \pm 7,6$ & $486,8 \pm 142,9$ \\
\hline \multirow{4}{*}{ Kelapa Sawit } & 1 & 525 & 0,12 & 4,16 & $3,8 \pm 0,15$ & $31,4 \pm 1,8$ & $29,6 \pm 2,8$ & $28,7 \pm 1,8 \quad 40,6 \pm 6,9$ & $374, \pm 188,9$ \\
\hline & 2 & 510 & 0,11 & 4,17 & $3,7 \pm 0,10$ & $28,4 \pm 1,2$ & $28,1 \pm 2,2$ & $27,9 \pm 1,6 \quad 48,5 \pm 4,8$ & $330,9 \pm 119,6$ \\
\hline & 3 & 60 & 0,41 & 3,61 & $3,3 \pm 0,06$ & $31,9 \pm 3,3$ & $29,3 \pm 3,2$ & $27,4 \pm 0,8 \quad 22,2 \pm 7,1$ & $515,5 \pm 116,9$ \\
\hline & Rerata & 365 & 0,21 & 3,98 & $3,6 \pm 0,22$ & $30,6 \pm 2,7$ & $28,9 \pm 2,8$ & $27,9 \pm 1,536,4 \pm 12,7$ & $410,2 \pm 161,6$ \\
\hline \multirow{4}{*}{ Jahe } & 1 & 60 & 0,18 & 3,94 & $3,6 \pm 0,06$ & $34,3 \pm 3,6$ & $29,2 \pm 1,2$ & $28,1 \pm 0,3 \quad 19,3 \pm 7,2$ & $398,1 \pm 163,1$ \\
\hline & 2 & 40 & 0,33 & 3,82 & $3,5 \pm 0,07$ & $32,8 \pm 3,0$ & $28,1 \pm 0,5$ & $27,4 \pm 0,5 \quad 21,6 \pm 5,6$ & $221,1 \pm 111,5$ \\
\hline & 3 & 140 & 0,12 & 3,953 & $3,8 \pm 0,09$ & $34,0 \pm 1,3$ & $28,6 \pm 0,8$ & $28,2 \pm 0,525,4 \pm 10,8$ & $528,9 \pm 163,3$ \\
\hline & Rerata & 80 & 0,21 & 3,9 & $3,6 \pm 0,13$ & $33,7 \pm 2,8$ & $28,6 \pm 1,0$ & $27,9 \pm 0,6 \quad 21,8 \pm 8,0$ & $392,8 \pm 204,7$ \\
\hline \multicolumn{2}{|c|}{ Rata-rata } & 219,33 & 0,14 & 4,07 & $3,6 \pm 0,12$ & $31,6 \pm 2,9$ & $28,3 \pm 1,9$ & $28,3 \pm 1,1 \quad 31,8 \pm 11,9$ & $429,9 \pm 147,1$ \\
\hline
\end{tabular}

\section{CO2 Emissions by Land Use}

The total emission from each use is obtained from the average of the results of measurements of the rhizosphere area both near the tree and far from the tree. ANOVA results show that there is no significant effect of land use on $\mathrm{CO} 2$ emissions. The measurement results show that the highest $\mathrm{CO} 2$ emissions are rubber land producing $486.8 \pm 142.9 \mathrm{mg} \mathrm{CO} 2 \mathrm{~m}-2$ hour-1 or equivalent to 42.6 tons ha-1th- 1 , oil palm land $410.2 \pm 161.6 \mathrm{mg} \mathrm{CO} 2 \mathrm{~m}-2$ hour-1 or the equivalent of 35.9 tons ha- 1 year- 1 and ginger $392.8 \pm 204.7 \mathrm{mg} \mathrm{CO} 2 \mathrm{~m}-2$ hour-1 or the equivalent of 34.4 tons ha-1th-1. (Table 1 and Figure 5). The amount of carbon emissions from small-scale agriculture on drained peatlands is close to the IPCC 2014 default value, which is between $40-73$ tons CO2 ha1 yr-1. Rumbang et al., (2009) also obtained similar results where rubber plantations produced more emissions than oil palm. Meanwhile, Khasanah and Van Noordwijk (2019) reported that oil palm CO2 emissions were higher than rubber land on small-scale agricultural land, with a $\mathrm{CO} 2$ emission value of $121.4 \mathrm{t} \mathrm{CO} 2$ ha-1 yr-1 on oil palm land and 79 for rubber land. $1 \mathrm{t} \mathrm{CO} 2$ ha-1 yr-1.

The value of $\mathrm{CO} 2$ emissions in rubber is higher than that of palm oil and ginger. One of the soil properties that affect the rate of emission is soil $\mathrm{pH}$. Soil $\mathrm{pH}$ value on rubber land is 4.08 , oil palm land is 3.98 and ginger land is 2.90 . The higher the $\mathrm{pH}$, the emission process due to the decomposition of organic matter in peat increases. The average $\mathrm{pH}$ in rubber fields is higher than in oil palm and ginger fields, so it is suspected that the high emission in $\mathrm{RB}$ land due to high soil $\mathrm{pH}$ causes the decomposition process to run faster. The results of research by Yahya et al., (2019) stated that the effect of $\mathrm{pH}$ on emissions was $91.41 \%$, so it was concluded that the higher the $\mathrm{pH}$, the greater the $\mathrm{CO} 2$ emissions produced. $\mathrm{CO} 2$ emissions measured every month show the highest emission in February, namely $456.52 \mathrm{mg} \mathrm{CO} 2 \mathrm{~m}-2$ hour- 1 , while the lowest in January was 357.37 mg CO2 m-2.hour-1 (Figure 7). The factors that cause the dynamics of the magnitude of $\mathrm{CO} 2$ emissions are very complex, and cannot be explained through this research.

\section{Effect of Roots on CO2 . Emissions}

Sampling at the point near the tree (NT) and far from the tree (FT) aims to see the difference in $\mathrm{CO} 2$ emissions in the area near the roots and areas far from the roots. These results indicate that the trenching at the FT point does not have a significant difference 


\section{Rita}

between the TR and UT areas on the resulting CO2 emissions. Similar conditions occur in the non-rhizosphere area (TR) at the NT point, and the rhizosphere area (UT) at the FT point does not have a significant difference in $\mathrm{CO} 2$ emissions. Thus, to see the effect of root respiration on the total emission produced, it can be done by adjusting the distance of sampling from the tree without the need for trenching. Hergoualc'h et al., (2017) also conducted a similar study with the assumption that total respiration at the far point of the tree is an indicator of heterotrophic respiration. Measurement of $\mathrm{CO} 2$ emissions at points near trees in the rhizosphere area is greater than in the non-rhizosphere area. Emissions in the rhizosphere area are total respiratory emissions from autotrophic and heterotrophic respiration processes, while non-rhizosphere areas are emissions from heterotrophic respiration processes. The accumulation of respiration processes in roots and decomposition causes the rhizosphere area to produce higher emissions than TR which is only a decomposition process. The value of heterotrophic respiration from rubber plantations was $61.4 \%$, and oil palm $57.4 \%$. This is in line with previous studies which showed that heterotrophic respiration was higher than autotrophic respiration, where Agus et al. (2010) obtained results of $62 \%$, Dariah et al., (2014) of $86 \%$, and Comeau et al., (2016) obtained results of $68-87 \%$.

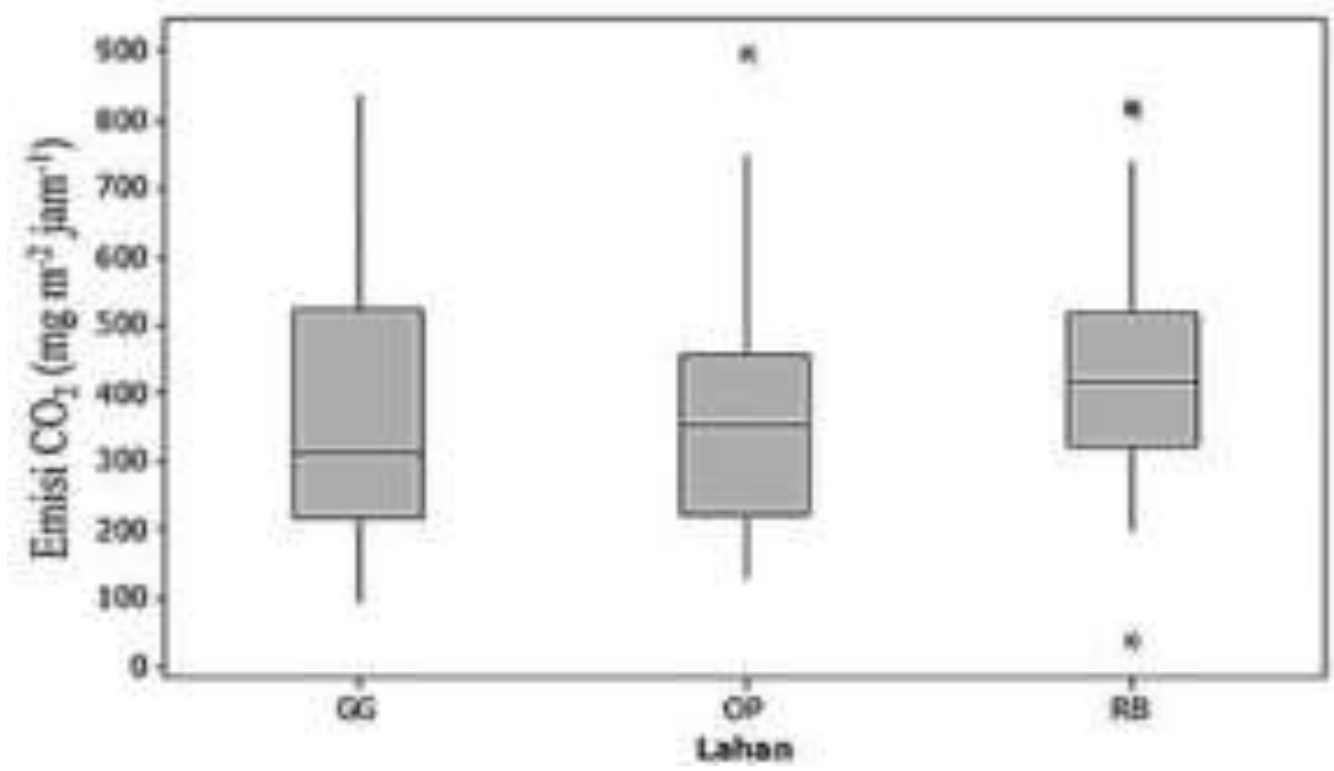

Figure 5. Amount of CO2 Emissions on Each Land Use Ginger (GG), Oil Palm (OP), and Rubber (RB) 


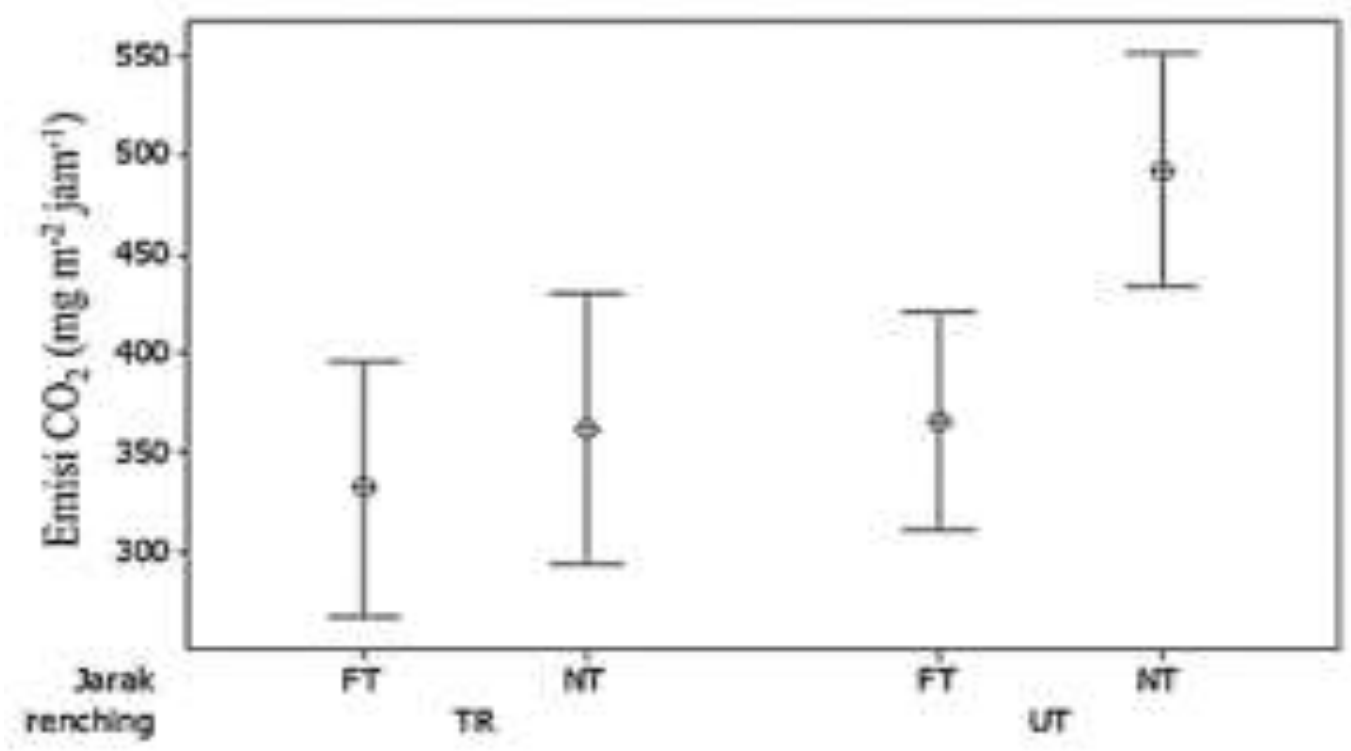

Figure 6. CO2 Emissions in Non-rhizosphere (UT) and Rhizosphere (TR) Areas Near Trees (NT) and Far from Trees (FT)

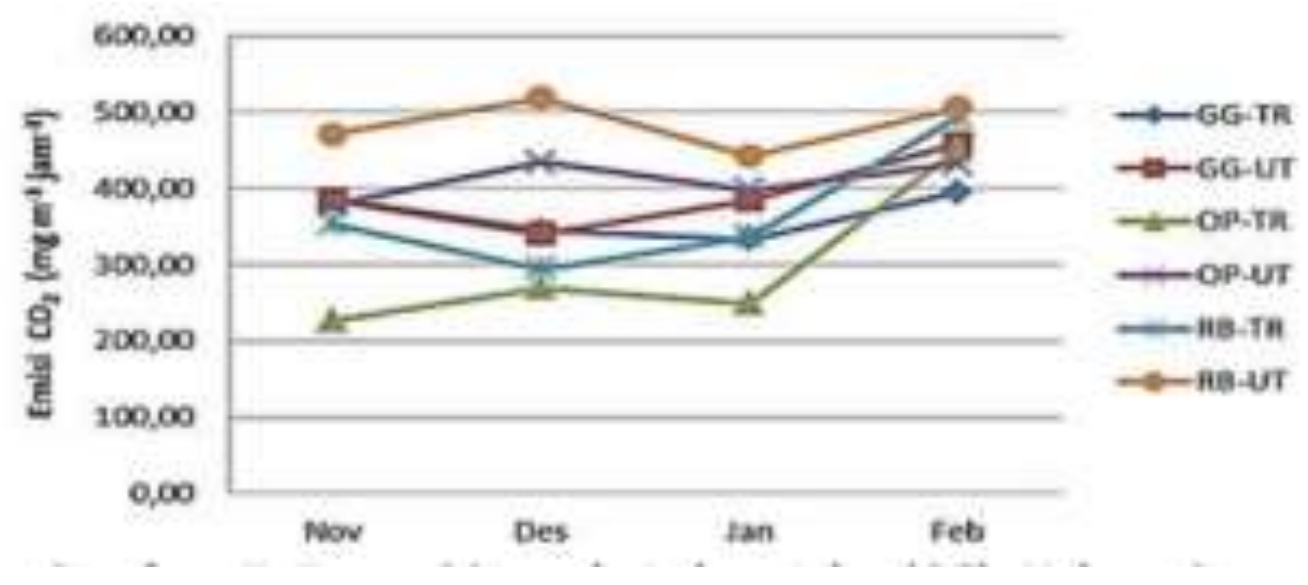

Figure 7 CO2 Emissions in Ginger, Oil Palm and Rubber Fields for Four Months

In the ginger field, the $\mathrm{CO} 2$ emissions produced in the rhizosphere area were not significantly different from the non-rhizosphere area. Trenching cannot separate $\mathrm{CO} 2$ emissions from heterotrophic respiration and total respiration in ginger fields because the roots of ginger plants do not spread far. It can be seen that at the time of trenching there was no cut root of the ginger plant, even though the point of trenching was only $10-20 \mathrm{~cm}$ from the ginger plant. This condition is one of the factors that causes emissions in rubber and oil palm fields to be higher than in ginger fields. Plant roots not only contribute to releasing $\mathrm{CO} 2$ emissions in the respiration process, but plant roots also release exudates such as carbohydrates, amino acids, ions, and enzymes that have the potential to increase respiratory activity in the root area (Hamer and Marschner, 2005; Kuzyakov et al., 2000). ; Subke et al., 2004). 


\section{Effect of Environmental Factors on $\mathrm{CO} 2$ Emissions}

The results obtained showed that there was no significant difference between the groundwater table in rubber and oil palm fields but it was significantly different from that of ginger $(\mathrm{P}<0.001)$. The groundwater table shows a positive correlation with $\mathrm{CO} 2$ emissions with a value of $\mathrm{r}=0.205 ; \mathrm{P}=0.017$. According to Couwenberg et al. (2010) data collected on GHG emissions, one of which is $\mathrm{CO} 2$ from tropical peatlands, shows a relationship between groundwater table, $\mathrm{pH}, \mathrm{C} / \mathrm{N}$ ratio, soil temperature, vegetation cover and land use. The average value for each measured environmental variable is shown in Table 1. Based on the results obtained, the average depth of the groundwater table in rubber and oil palm fields is $37 \mathrm{~cm}$ and $36 \mathrm{~cm}$, while the ginger area is $22 \mathrm{~cm}$. The depth of the groundwater table in rubber and oil palm fields which did not differ significantly was due to the construction of drainage channels by farmers for the purpose of controlling. While in ginger land, farmers make canal blocking with the aim that the land is not too dry, but not flooded so that ginger plants can grow well. This shows that the aerobic oxidation process in rubber and oil palm fields is higher than in ginger fields, which results in higher emissions produced in rubber and oil palm fields than ginger fields. Ishikura et al. (2019) also explained that a decrease in the depth of the groundwater table will increase $\mathrm{CO} 2$ emissions due to the acceleration of the decomposition of organic matter that makes up peat. The effect of groundwater level was also reported by Hooijer et al. (2010 and 2012) show a positive relationship between $\mathrm{CO} 2$ emissions and the groundwater table, where the deeper the groundwater table, the higher the $\mathrm{CO} 2$ emissions. The same thing was also conveyed by Hirano et al. (2012) that an increase in depth of $10 \mathrm{~cm}$ will increase emissions by $0.89 \mathrm{t} \mathrm{C} \mathrm{m-2} \mathrm{yr-1} \mathrm{on} \mathrm{tropical} \mathrm{peatlands} \mathrm{in}$ Palangkaraya. On peatlands that function as agricultural areas the range is between 40 60 tons CO2eq ha-1 year-1 at a groundwater level of $70 \mathrm{~cm}$ (Hergoualc'H and Verchot, 2011; Melling et al., 2005; Murdiyarso et al., 2010; Couwenberg et al., 2010; Hooijer et al., 2006, 2010) Air temperature in the range of 27-400C has no significant effect on $\mathrm{CO} 2$ emissions. Agus (2010) also shows that air temperature has no effect on $\mathrm{CO} 2$ gas emissions. This is probably due to the minimum and maximum temperature differences that are not too wide. Meanwhile, Kwon et al., (2013) stated that high soil surface temperatures cause drought stress, thereby suppressing microbial decomposition activity.

\section{CONCLUSION}

$\mathrm{CO} 2$ emissions from small-scale agriculture from rubber and oil palm plantations and ginger farming on drained peatlands show different magnitudes. This shows that small-scale agriculture carried out by community groups has a fairly large emission contribution. Efforts to reduce emissions from small-scale agriculture on drained peatlands are urgently needed so that the government's target to reduce carbon emissions can be achieved.

\section{REFERENCES}

Anih Sri Suryani, "Penanganan Asap Kabut Akibat Kebakaran Hutan di Wilayah Perbatasan Indonesia", Aspirasi Vol 3, No,1, Juni 2012, hal. 60Vol 3, No,1, Juni 2012, hal. 60 
Agus, F.E., Runtunuwu, T., June, E., Susanti, H., Komara, I., Las \& van Noordwijk, M. 2009. Carbon budget in land use transitions to plantation. J Penelitian dan Pengembangan Pertanian 29(4): 119-126.

Barchia, M.F. 2009. Agroekosistem Tanah Mineral Masam. Yogyakarta: Gadjah Mada University Press.

Brown, S., Gillespie, A.J.R \& Lugo, A.E. 1989. Biomass estimation methods for tropical forest with application to forest inventory Data. Forest Science 35(4): 881-902.

Dinas Perkebunan Provinsi Riau. 2009. Statistik Perkebunan Riau. Pekanbaru.

Galbraith, H., Amerasinghe, P \& Lee, H.A. 2005. The effects of Agricultural Irrigation on Wetland Ecosystems in Developing Countries: A literature review. CA Discussion Paper 1 Colombo, Sri Lanka: Comprehensive Assessment Secretariat.

Hooijer, A., Silvius, M., Wosten., H \& Page, S. 2006. Peat-CO2 . Assessment of CO2 Emissions from Drained Peatlands in SE Asia.

Handayani, E.P. 2009. Emisi karbondioksida $(\mathrm{CO} 2)$ dan metan $(\mathrm{CH} 4)$ pada perkebunan kelapa sawit di lahan gambut yang memiliki keragaman dalam ketebalan gambut dan umur tanaman. Disertasi: Bogor. Institut Pertanian Bogor.

Istomo. 2002. Kandungan Fosfor dan Kalsium serta Penyebarannya Pada Tanah dan Tumbuhan Hutan Rawa Gambut. Disertasi Program Pascasarjana. Bogor: IPB.

Las, I..K., Nugroho \& Hidayat, A. 2009. Strategi Pemanfaatan Lahan Gambut Untuk Pengembangan Pertanian Berkelanjutan. Balai Besar Penelitian dan Pengembangan Sumberdaya Lahan Pertanian. Bogor. J Pengembangan Inovasi Pertanian 2(4): 295-298.

Meiling, L \& Goh, K.J. 2008. Sustainable oil Palm cultivation on tropical peatland. Kualalumpur: Trofical Peat Research Laboratory and Applied Agricultural Resources.

Melling, L., Hatano, R \& Goh, K.J. 2005. Soil CO2 flux from three Ecosystems in Tropical Peatland of Sarawak. Malaysia: Tellus B 57(1): 1-11.

Noor, M. 2001. Pertanian Lahan Gambut; Potensi dan Kendala. Yogyakarta: Kanisius.

Riwandi. 2003. Indikator stabilitas gambut berdasarkan analisis kehilangan karbon organik, sifat fisikokimia dan komposisi bahan gambut. Jurnal Penelitian UNIB 9(1): 25-36.

Sabiham S. 2007. Pengembangan lahan secara berkelanjutan sebagai dasar dalam pengelolaan gambut di Indonesia. Makalah Utama Seminar Nasional Pertanian Lahan Rawa. Kapuas 3-4 Juli 2007.

Sabiham, S \& Ismangun, M. 1997. Potensi dan kendala pengembangan lahan gambut untuk pertanian. Proseding Simposium Nasional dan Konggres V PERAGI. Jakarta, 25-27 Januari 1996.

Steel, R.G.D \& Torrie, J.H. 1980. Analysis of covariance, In: Principles and Procedures of Statistics: a Biometrical Approach, New York: McGraw-Hill.

Subagyo, H., Marsoedi \& Karama, A.S. 1996. Prospek pengembangan lahan gambut untuk pertanian; Seminar Pengembangan Tehnologi Berwawasan Lingkungan Untuk Pertanian Pada Lahan Gambut. Dalam Rangka Peringatan Dies Natalis ke 33 Bogor: IPB Tgl 26 September 1996.

[WWF] Word Wild Found. 2008. How Pulp \& Paper and Palm Oil from Sumatra Increase Global Climate Change and Drive Tigers and Elephants to Local Extinction. WWF Indonesia Technical Report 